\title{
APLIKASI DELIVERY ORDER MAKANAN DAN MINUMAN BERBASIS WEB PADA RESTORAN MANG KABAYAN
}

\author{
Syifa Nur Rakhmah ${ }^{1}$, Reza $^{2}$, Kardinal Novel $^{3}$ \\ Sistem Informasi, STMIK Nusa Mandiri Jakarta \\ Jl. Damai No. 8, Warung Jati Barat (Margasatwa), Jakarta Selatan \\ Sistem Informasi, Universitas Bina Sarana Informatika \\ Jl. Kamal Raya No. 18, Ringroad Barat, Cengkareng, Jakarta Barat \\ syifa.snk@nusamandiri.ac.id ${ }^{2}$ reza1512@bsi.ac.id ${ }^{3}$ kadinar.ked@bsi.ac.id
}

\begin{abstract}
The utilization of smartphone technology in various aspects has now been felt, without exception reaching restaurants that want to use technology for the satisfaction of customers and the benefits of restaurants. Humans in general want everything to be easily done, as well as restaurant customers who want to order menus easily in the sense that it is not complicated and does not take a long time. It's easy to order the menu in question without having to queue and without waiting for the waiter to be busy with other customers. Restaurant customers can also take time to order orders according to their needs so they are not disturbed by the presence of a waiter who is waiting for the order. The preparation of this study uses two research methods, namely, data collection methods and software development methods, namely using the waterfall method. To overcome the problems that the authors describe, a web-based application is made to make it easier for restaurants and customers to order food. With the use of media websites that have been published can facilitate food ordering in real time..
\end{abstract}

Keywords : Waterfall, Application, Customer, Web Based, Real-time

\section{PENDAHULUAN}

Restoran merupakan tempat usaha komersial yang ruang lingkup kegiatannya menyediakan hidangan makanan dan minuman untuk pengunjung yang bersifat umum. Sebagian besar restoran masih menggunakan sistem pemesanan menu secara manual seperti pelayan mencatat pemesanan menu pengunjung, dan pengunjung membayar menu pesanannya ke bagian kasir. Biasanya restoran yang dikunjungi banyak pengunjung, dimungkinkan menghadapi masalah seperti keterlambatan pemesanan menu, kesalahan pencatatan menu, dan kesalahan dalam transaksi pembayaran. Tujuan dari penelitian ini adalah untuk menghasilkan sebuah aplikasi yang mampu mengatasi masalah pelayanan, seperti keterlambatan pemesanan menu, kesalahan pencatatan menu, dan kesalahan transaksi pembayaran serta dapat melakukan pemesanan dengan sistem Delivery Order yang dapat di akses melalui website (Febriyansyah, Bijaksana, Negara, \& Safriadi, 2017).

Berdasarkan informasi yang didapatkan oleh penulis dengan mengadakan Observasi langsung ke Mang Kabayan Harapan Indah, mengenai perkembangan data Delivery Order untuk persentase yang didapatkan oleh restoran Mang Kabayan sangatlah mengkhawatirkan yaitu 35,7 persen perbulan. Dimana persentase tersebut didapatkan dari 4 cabang restoran Mang Kabayan yang ada di Bekasi yang beralamatkan di Harapan Indah,Bintaro, Kalimalang, dan Cibubur.

Terdapat berbagai faktor penyebab minimnya persentase tersebut yaitu pemasaran yang kurang menarik, dan terutama untuk mengakses pesanan hanya dapat dilakukan dengan menggunakan telepon. Masyarakat pada umumnya menginginkan segala sesuatu dapat dengan mudah dikerjakan, dengan mudah dalam artian tidak rumit dan tidak memakan waktu yang lama serta dapat dilakukan dimana saja yang diinginkan. Seperti mudah dalam memesan menu yang dimaksud adalah tanpa harus mengantri dan tanpa harus menunggu pelayan yang sibuk dengan pelanggan lainnya.

Dengan permasalahan diatas, penulis mengusulkan untuk dibuatkan program yang dapat memanajemen pemesanan menu sesuai dengan kebutuhan pelanggan, dan melakukan pemesanan menu yang dapat dilakukan dengan menggunakan smartphone guna meningkatkan persentase dan mempermudah pelanggan melakukan pemesanan serta menciptakan kepuasan atas pelayanan restoran tersebut. Selain untuk memudahkan pelanggan dalam melakukan pemesanan sistem ini juga dapat mempermudahkan pihak restoran seperti mengatur antrian pesanan sesuai waktu pemesanan pelanggan, mengatur status ketersediaan menu, kesalahan pencatatan menu, dan dapat mengkontrol jumlah pesanan.

\section{METODE}

Terdapat dua meode dalam penyusunan penulisan ini, yaitu metode pengembangan perangkat lunak dan metode pengumpulan data.

\subsection{Metode Pengembangan Perangkat lunak}

Metode yang digunakan pada pembuatan aplikasi ini menggunakan metode waterfall. Menurut (M.Shalahuddin, 2013), menjelaskan 
bahwa metode waterfall terbagi menjadi lima tahapan, yaitu:

1. Analisa kebutuhan perangkat lunak

Proses pengumpulan kebutuhan aplikasi menggunakan pengumpulan data pelanggan, data makanan, dan harga makanan. dilakukan secara interaktif untuk menspesifikasi kebutuhan perangkat lunak agar dapat dipahami perangkat lunak seperti apa yang dibutuhkan oleh user. Misalkan cara pemesanan, cara pembayaran, dan stok ketersediaan makanan.

a. Halaman Administrator

1) Admin dapat menambah, mengubah dan menghapus data produk.

2) Admin dapat mengecek dan memproses data transaksi yang dilakukan pengunjung.

3) Admin dapat menambahkan dan mengubah kategori dan data produk

4) Admin dapat mengubah data anggota

5) Admin dapat mengelola konfirmasi pembayaran

6) Admin dapat mengelola laporan penjualan

b. Halaman Anggota

1) Anggota dapat melakukan transaksi pembelian produk

2) Anggota dapat melakukan proses pembelian produk

3) Anggota dapat melakukan proses konfirmasi pembayaran

4) Anggota dapat mengubah password

5) Anggota dapat melihat keranjang belanja

6) Anggota dapat mencetak struk pembayaran

c. Halaman Pengunjung

1) Pengunjung hanya dapat melihat makanan dan minuman yang dijual

2) Pengunjung dapat melakukan pendaftaran menjadi anggota baru

3) Pengunjung dapat login apabila sudah menjadi anggota

2. Desain

Dalam tahap pembuatan desain, penulis merancang terlebih dahulu tampilan untuk rancangan apikasi tersebut. Untuk merancang aplikasi penulis menggunakan rancangan antarmuka, dan untuk aliran proses ERD, LRS, dan Struktur Navigasi.

a. ERD

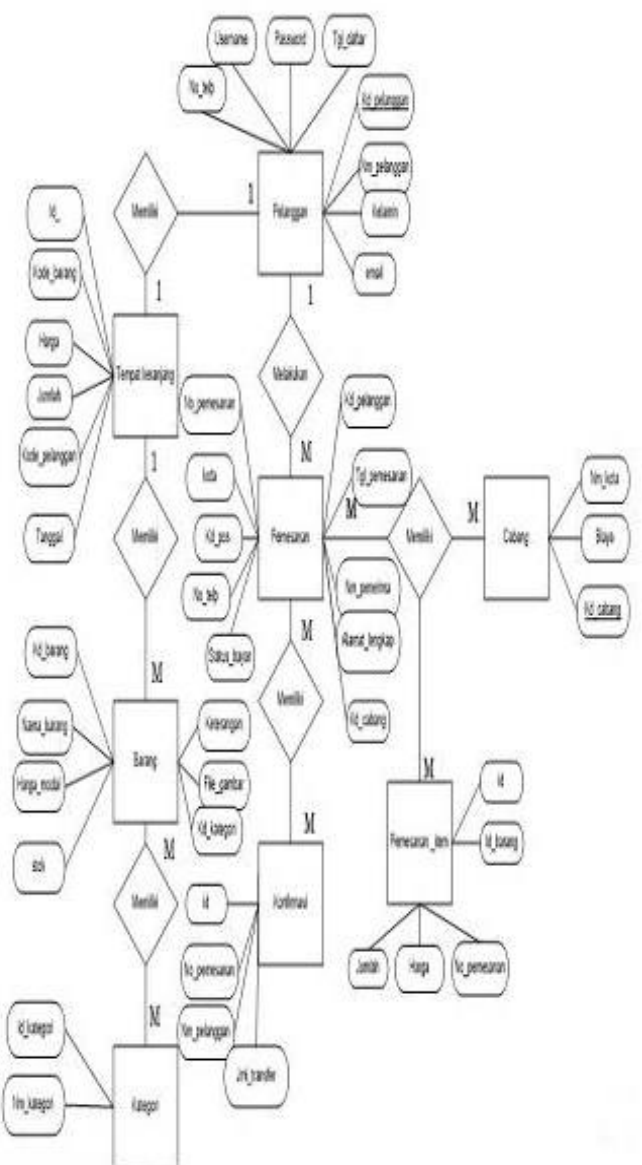

Gambar 1. Entity Relationship Diagram Pada Sistem Aplikasi Mang Kabayan

b. LRS

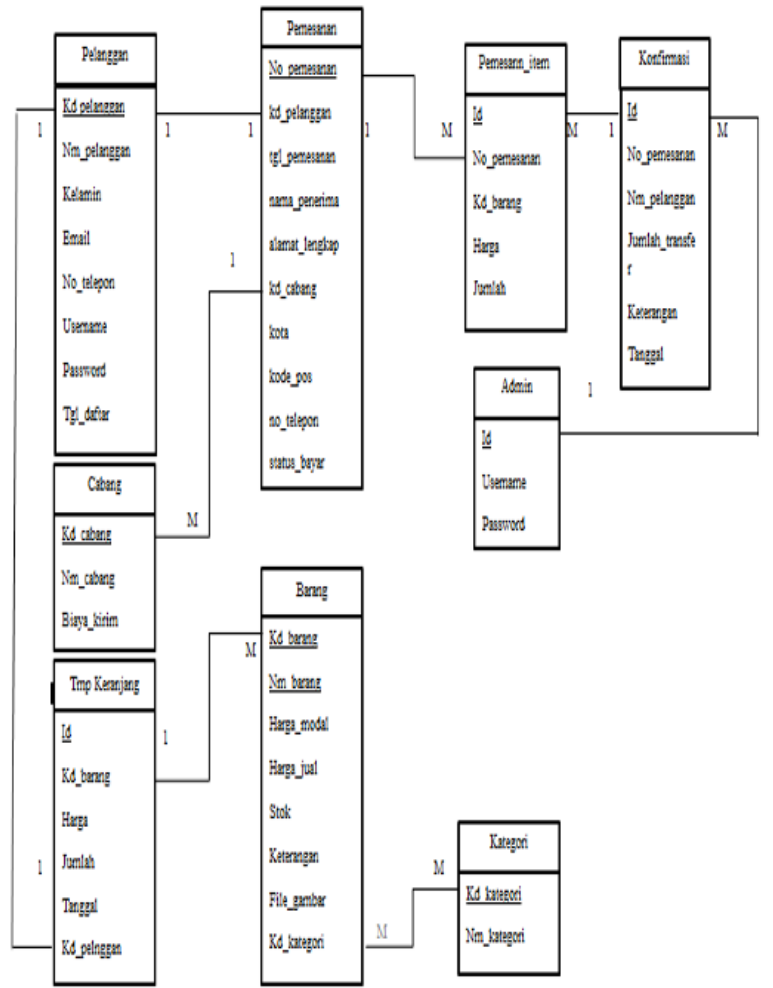

Gambar 2. Logical Record Strukture 
c. Struktur Navigasi

Pada halaman index menggunakan struktur navigasi non linier karena pada rangkaian beranda, artikel, produk, produk Permintaan, cara belanja, testimoni, login member dan daftar member dapat diakses secara acak atau tidak terurut.

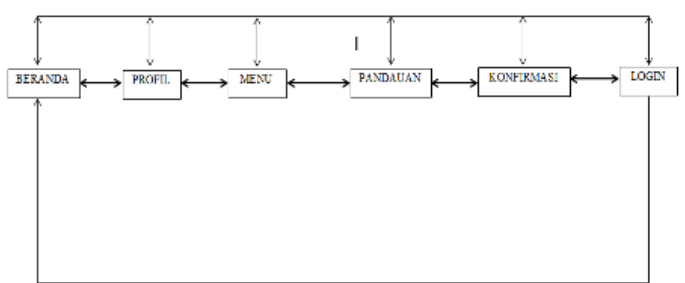

Gambar 3. Struktur Navigasi Halaman Pengunjung Utama

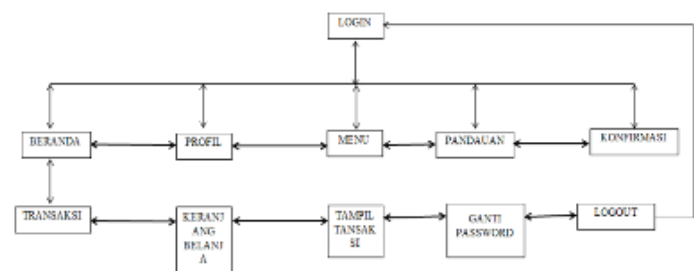

Gambar 4. Struktur Navigasi Halaman Pelanggan

\section{Pengkodean}

Dalam tahap ini pengkodean dibuat agar pembuatan ID bisa dikodekan supaya terlihat unik.

a. Kode Barang

Setiap barang memiliki kode masingmasing sehingga kita dapat membedakan satu dengan lainnya.
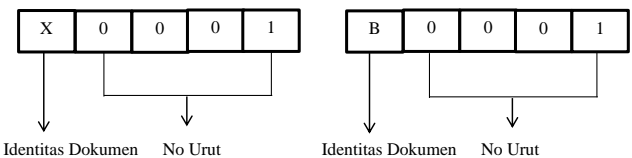

Gambar 5. Kode Barang

b. Kode Kategori

Setiap kategori memiliki kode masingmasing sehingga kita dapat membedakan satu dengan lainnya.

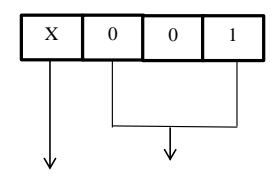

Identitas Dokumen No Urut

\section{Gambar 6. Kode Kategori}

c. Kode Pelanggan

Setiap Pelanggan memiliki kode masingmasing sehingga kita dapat membedakan satu dengan lainnya.

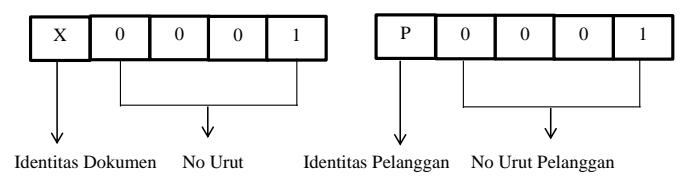

Gambar 7. Kode Pelanggan

d. Kode Cabang

Setiap cabang memiliki kode masingmasing sehingga kita dapat membedakan satu dengan lainnya.
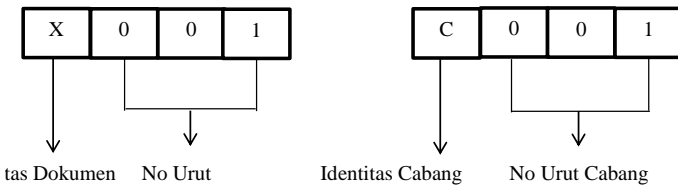

Gambar 8. Kode Cabang

e. Kode Pemesanan

Setiap barang memiliki kode masingmasing sehingga kita dapat membedakan satu dengan lainnya.

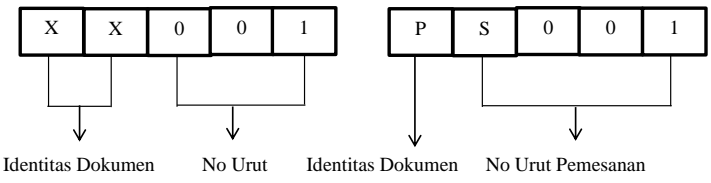

Gambar 9. Kode Pemesanan

4. Pengujian

Pengujian dilakukan dengan menggunakan black box yang di buat penulis terhadap dosen pembimbing. Hal ini dilakukan untuk meminimalisir kesalahan dan memastikan keluaran yang dihasilkan sesuai dengan yang diinginkan.

5. Pendukung dan pemeliharaan

Tidak menutup kemungkinan sebuah aplikasi mengalami perubahan ketika sudah

dikirimkan ke user. Perubahan bisa saja terjadi karena adanya kesalahan yang muncul, perubahan harga makanan, menu makanan baru, tampilan website baru yang dapat menarik perhatian pelanggan. Tahap pendukung atau pemeliharaan dapat mengulangi proses pengembangan mulai dari analisa spesifikasi untuk aplikasi yang sudah ada, tapi tidak untuk membuat aplikasi baru.

\subsection{Teknik Pengumpulan Data}

Dalam penyusunan Tugas Akhir ini, penulis mengumpulkan data dengan menggunakan metode-metode sebagai berikut:

1. Pengamatan(Observasi)

2. Pada metode ini penulis melakukan pengamatan langsung ke restoran Mang Kabayan Harapan Indah yang berlokasikan di Bekasi Utara. Dari pengamatan secara langsung tersebut penulis mengamati seberapa banyak pesanan Delivery Order 
perharinya, dan penulis mengamati website yang beralamatkan www.kfcku.com sebagai acuan dan referensi.

3. Wawancara (interview)

Dalam penyusunan penulisan ini, untuk mendapatkan informasi secara lengkap maka penulis melakukan suatu metode tanya jawab dengan bapak Endang selaku manajer restoran mang kabayan Harapan Indah yang bertugas mengatur berkembangnya restoran serta bertanggung jawab penuh atas restoran tersebut mengenai semua kegiatan yang berhubungan dengan pemesanan makanan secara Delivery Order.

4. Studi Pustaka

Dalam metode ini, pengumpulan data dilakukan dengan cara mempelajari buku-

buku yang menduku, termasuk didalamnya literatur tentang penulisan dan mengenai hal-hal yang mendukung pembuatan program aplikasi. Juga mempelajari dari sumber data yang lain seperti dari internet dan CD reverensi program..

\section{PEMBAHASAN}

\subsection{Tampilan Sistem}

Administrator harus melakukan login terlebih dahulu untuk dapat menggunakan hak akses yang tersedia. Jika login berhasil maka menu-menu yang sesuai dengan kategori user tersebut akan ditampilkan.

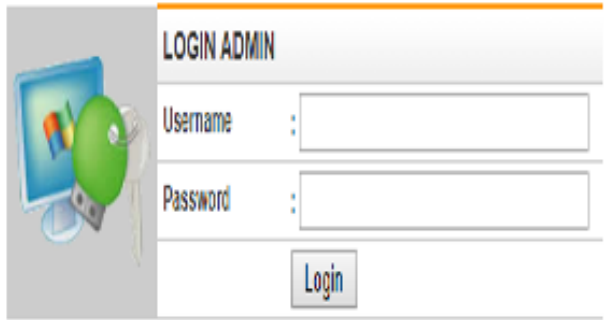

Gambar 10. Login Admin

Untuk mengelola data cabang rumah makan Mang Kabayan bisa dikelola pada halaman admin. Halaman ini diperlukan dikarenakan rumah makan Mang Kabayan selalu bertambah pada setiap wilayah.

\begin{tabular}{|c|c|}
\hline & $L^{\text {nuW }}$ \\
\hline Wo Nemp Poinsis & 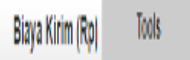 \\
\hline 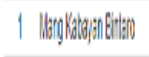 & 1000) Eif lete \\
\hline 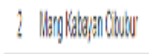 & 100. Eis leste \\
\hline 1 | IH: & 100. Eis chete \\
\hline 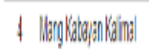 & 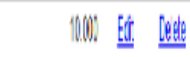 \\
\hline
\end{tabular}

Gambar 11. Data Cabang
Untuk mengelola pengkategorian menu pada rumah makan Mang Kabayan diperlukan halaman pengelolaan seperti gambar dibawah ini.

\begin{tabular}{|c|c|c|}
\hline No & Nama Kategori & Tooks \\
\hline 1 & Mecu Abcestzer & E⿱㇒冋l Delate \\
\hline 2 & Mecu Ajam & Eol \\
\hline 3 & Meeu Favert & Eal \\
\hline 4 & Meeu Nasil & Eal \\
\hline 5 & Meeu Pakel & Edt \\
\hline 6 & Mew Soscal & Edt \\
\hline 7 & Mnuman & Eot \\
\hline
\end{tabular}

\section{Gambar 12. Kategori Menu}

Pengelolaan menu yang ada pada rumah makan Mang Kabayan dikelola pada form data barang supaya keseluruhan menu bisa dikelola pada halaman form yang sama.

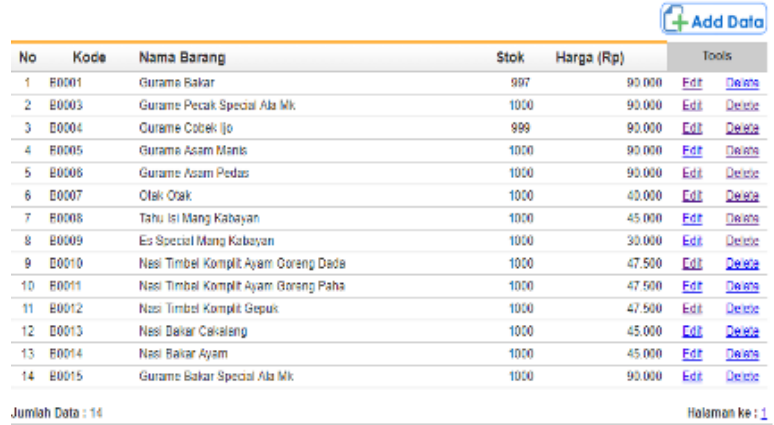

Gambar 13. Form Data Barang

Berikut adalah tampilan halaman utama untuk pengunjung dan customer (pelanggan).

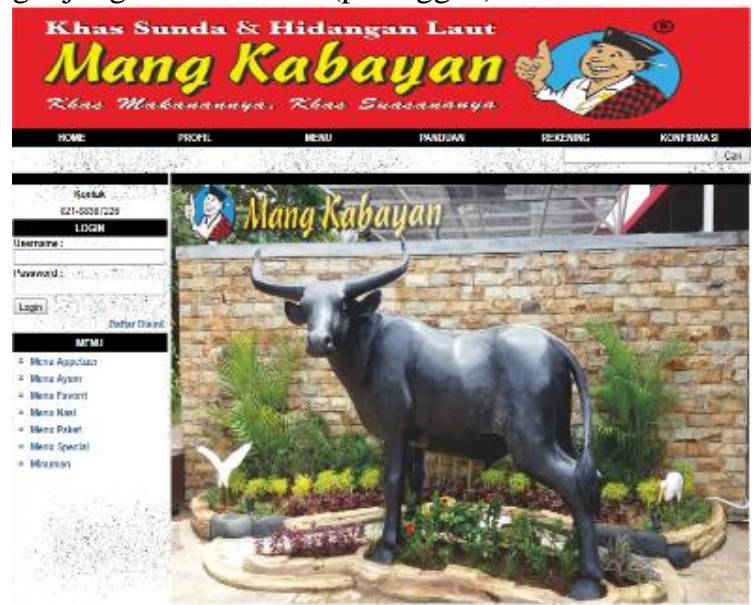

Gambar 14. Halaman Utama Website

Pada halaman ini untuk melihat menu-menu apa saja yang tersedia pada rumah makan Mang Kabayan, pelanggan bisa melihatnya pada halaman ini. 


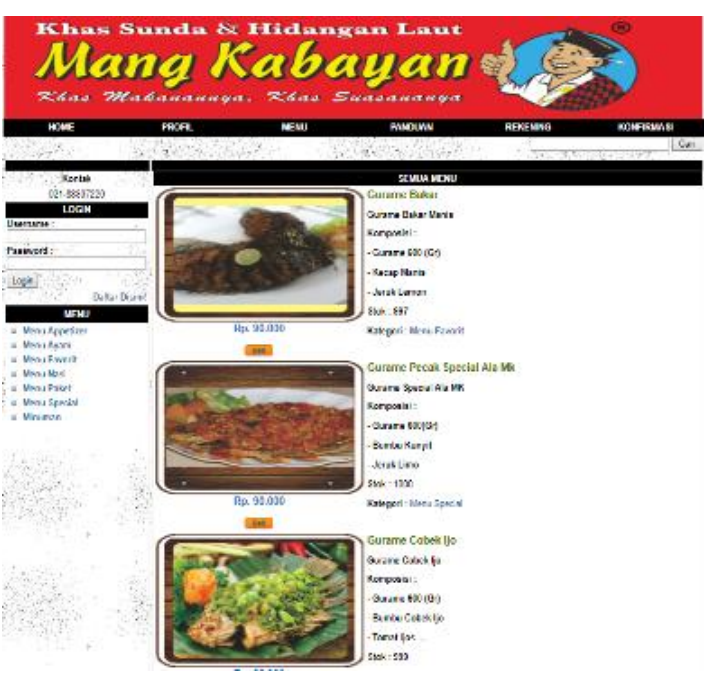

Gambar 15. Halaman Melihat List Menu

Menu yang telah dipesan akan masuk pada halaman keranjang belanja dan akan secara otomatis masuk pada halaman detail transaksi.

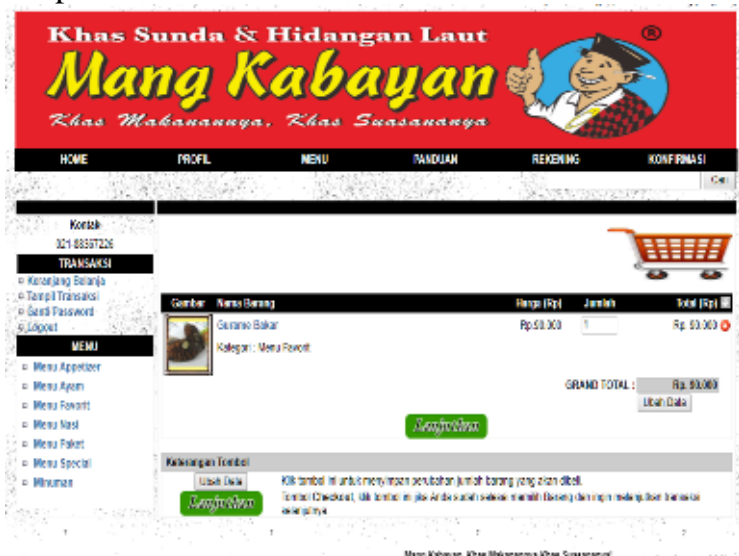

Gambar 16. Halaman Pemesanan

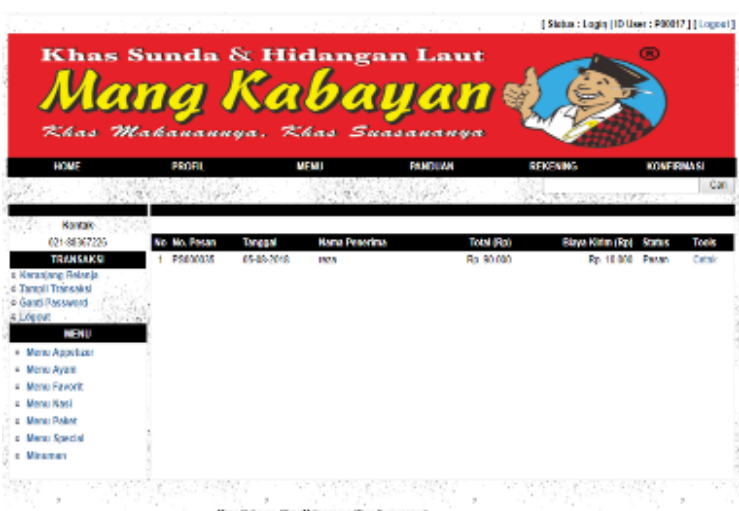

Gambar 17. Halaman Detail Transaksi Pemesanan

\subsection{Pengujian Blackbox Testing}

Agar seluruh inputan pada program sesuai maka perlu adanya pengujian program. Salah satu bentuk pengujian yang dilakukan adalah blackbox testing. a. Pengujian Terhadap Form Login Admin

Tabel 1. Hasil Pengujian Blackbox Testing Form Login Admin

\begin{tabular}{|c|c|c|c|c|c|}
\hline No & $\begin{array}{c}\text { Skenario } \\
\text { pengujia } \\
\text { n }\end{array}$ & $\begin{array}{l}\text { Test } \\
\text { case }\end{array}$ & $\begin{array}{c}\text { Hasil } \\
\text { yang } \\
\text { diharapk } \\
\text { an } \\
\end{array}$ & $\begin{array}{c}\text { Hasil } \\
\text { penguj } \\
\text { ian }\end{array}$ & $\begin{array}{l}\text { Kesim } \\
\text { pulan }\end{array}$ \\
\hline 1. & $\begin{array}{l}\text { Usernam } \\
\text { e dan } \\
\text { password } \\
\text { tidak } \\
\text { diisi } \\
\text { kemudian } \\
\text { klik } \\
\text { tombol } \\
\text { login }\end{array}$ & $\begin{array}{l}\text { Userna } \\
\text { me } \\
\text { (Koson } \\
\text { g) } \\
\text { Passwo } \\
\text { rd } \\
\text { (Koson } \\
\text { g) }\end{array}$ & $\begin{array}{l}\text { Sistem } \\
\text { akan } \\
\text { menolak } \\
\text { akses } \\
\text { user dan } \\
\text { menampi } \\
\text { lkan } \\
\text { "Data } \\
\text { username } \\
\text { dan } \\
\text { password } \\
\text { tidk } \\
\text { boleh } \\
\text { kosong" }\end{array}$ & $\begin{array}{l}\text { Sesuai } \\
\text { harapa } \\
\mathrm{n}\end{array}$ & Valid \\
\hline 2. & $\begin{array}{l}\text { Mengetik } \\
\text { kan } \\
\text { username } \\
\text { dan } \\
\text { password } \\
\text { tidak } \\
\text { diisi atau } \\
\text { kosong } \\
\text { kemudian } \\
\text { klik } \\
\text { tombol } \\
\text { login }\end{array}$ & $\begin{array}{l}\text { Userna } \\
\text { me } \\
\text { (admin } \\
\text { ) } \\
\text { Passwo } \\
\text { rd } \\
\text { (Koson } \\
\text { g) }\end{array}$ & $\begin{array}{l}\text { Sistem } \\
\text { akan } \\
\text { menolak } \\
\text { akses } \\
\text { user dan } \\
\text { menampi } \\
\text { lkan } \\
\text { "Data } \\
\text { Password } \\
\text { Tidak } \\
\text { Boleh } \\
\text { Kosong", }\end{array}$ & $\begin{array}{l}\text { Sesuai } \\
\text { harapa } \\
n\end{array}$ & Valid \\
\hline 3. & $\begin{array}{l}\text { Usernam } \\
\text { e tidak } \\
\text { diisi } \\
\text { (kosong) } \\
\text { dan } \\
\text { password } \\
\text { diisi } \\
\text { kemudian } \\
\text { klik } \\
\text { tombol } \\
\text { login }\end{array}$ & $\begin{array}{l}\text { Userna } \\
\text { me } \\
\text { (Koson } \\
\text { g) } \\
\text { Passwo } \\
\text { rd } \\
\text { (admin } \\
\text { ) }\end{array}$ & $\begin{array}{l}\text { Sistem } \\
\text { akan } \\
\text { menolak } \\
\text { akses } \\
\text { user dan } \\
\text { menampi } \\
\text { lkan } \\
\text { "Data } \\
\text { Usernam } \\
\text { e Tidak } \\
\text { Boleh } \\
\text { Kosong!" }\end{array}$ & $\begin{array}{l}\text { Sesuai } \\
\text { harapa } \\
n\end{array}$ & Valid \\
\hline 4. & $\begin{array}{l}\text { Mengetik } \\
\text { kan salah } \\
\text { satu } \\
\text { kondisi } \\
\text { salah } \\
\text { pada } \\
\text { username } \\
\text { atau } \\
\text { password } \\
\text { kemudian } \\
\text { klik } \\
\text { tombol } \\
\text { login }\end{array}$ & $\begin{array}{l}\text { Userna } \\
\text { me:ad } \\
\text { min } \\
\text { (benar) } \\
\text { Passwo } \\
\text { rd:adm } \\
\text { in1 } \\
\text { (salah) }\end{array}$ & $\begin{array}{l}\text { Sistem } \\
\text { akan } \\
\text { menolak } \\
\text { akses } \\
\text { user dan } \\
\text { menampi } \\
\text { lkan } \\
\text { "Data } \\
\text { Usernam } \\
\text { e dan } \\
\text { Password } \\
\text { Anda } \\
\text { Belum } \\
\text { Benar". }\end{array}$ & $\begin{array}{l}\text { Sesuai } \\
\text { harapa } \\
n\end{array}$ & Valid \\
\hline 5. & $\begin{array}{l}\text { Mengetik } \\
\text { kan } \\
\text { username } \\
\text { dan } \\
\text { password } \\
\text { dengan } \\
\text { data yang } \\
\text { benar } \\
\text { kemudian } \\
\text { klik } \\
\text { tombol } \\
\text { login }\end{array}$ & $\begin{array}{l}\text { Userna } \\
\text { me:ad } \\
\text { min } \\
\text { (benar) } \\
\text { Passwo } \\
\text { rd:adm } \\
\text { in } \\
\text { (benar) }\end{array}$ & $\begin{array}{l}\text { Sistem } \\
\text { menerim } \\
\text { a akses } \\
\text { login dan } \\
\text { kemudian } \\
\text { langsung } \\
\text { menampi } \\
\text { lkan } \\
\text { menu } \\
\text { utama. }\end{array}$ & $\begin{array}{l}\text { Sesuai } \\
\text { harapa } \\
n\end{array}$ & Valid \\
\hline
\end{tabular}


b. Pengujian Terhadap Form Member Pendaftaran Baru

Tabel 2. Hasil Pengujian Blackbox Testing Form Pendaftaran Customer

\begin{tabular}{|c|c|c|c|c|c|}
\hline No & $\begin{array}{c}\text { Skenario } \\
\text { pengujian }\end{array}$ & Test case & $\begin{array}{c}\text { Hasil yang } \\
\text { diharapka } \\
n\end{array}$ & $\begin{array}{c}\text { Hasil } \\
\text { penguj } \\
\text { ian }\end{array}$ & $\begin{array}{c}\text { Kesi } \\
\text { mpul } \\
\text { an }\end{array}$ \\
\hline & $\begin{array}{l}\text { Nama } \\
\text { pelanggan, } \\
\text { email, } \\
\text { no.telepon, } \\
\text { username, } \\
\text { password } \\
\text { dan } \\
\text { konfirmasi } \\
\text { password } \\
\text { tidak diisi } \\
\text { kemudian } \\
\text { klik tombol } \\
\text { daftar }\end{array}$ & $\begin{array}{l}\text { Nama } \\
\text { pelangga: } \\
\text { (kosong) } \\
\text { Email: } \\
\text { (kosong) } \\
\text { No.telepon: } \\
\text { (kosong) } \\
\text { Username: } \\
\text { (kosong) } \\
\text { Password: } \\
\text { (kosong) } \\
\text { Konfirmasi } \\
\text { password: } \\
\text { (kosong) }\end{array}$ & $\begin{array}{l}\text { Sistem } \\
\text { akan } \\
\text { menolak } \\
\text { akses user } \\
\text { dan } \\
\text { menampilk } \\
\text { an "Data } \\
\text { nama } \\
\text { pelanggan,a } \\
\text { lamat } \\
\text {,email,no. } \\
\text { Telepon,us } \\
\text { ername } \\
\text {,password,k } \\
\text { onfirmasi } \\
\text { Password } \\
\text { masih } \\
\text { kosong" }\end{array}$ & $\begin{array}{l}\text { Sesuai } \\
\text { harapa } \\
\mathrm{n}\end{array}$ & Valid \\
\hline & $\begin{array}{l}\text { Mengetikka } \\
\mathrm{n} \text { nama } \\
\text { pelanggan } \\
\text { dan email, } \\
\text { no.telepon, } \\
\text { username,p } \\
\text { assword, } \\
\text { konfirmasi } \\
\text { password } \\
\text { tidak diisi } \\
\text { kemudain } \\
\text { klik tombol } \\
\text { daftar }\end{array}$ & $\begin{array}{l}\text { Nama } \\
\text { pelanggan:( } \\
\text { Reza) } \\
\text { Email:(kos } \\
\text { ong) } \\
\text { No. } \\
\text { Telepon:(k } \\
\text { osong) } \\
\text { Username: } \\
\text { (kosong) } \\
\text { Password: } \\
\text { (kosong) } \\
\text { Konfirmasi } \\
\text { Password: } \\
\text { (kosong) }\end{array}$ & $\begin{array}{l}\text { Sistem } \\
\text { akan } \\
\text { menolak } \\
\text { akses user } \\
\text { dan } \\
\text { menampilk } \\
\text { an "Data } \\
\text { alamat } \\
\text {,email,no. } \\
\text { Telepon,us } \\
\text { ername } \\
\text {,password,k } \\
\text { onfirmasi } \\
\text { Password } \\
\text { masih } \\
\text { kosong", }\end{array}$ & $\begin{array}{l}\text { Sesuai } \\
\text { harapa } \\
\mathrm{n}\end{array}$ & Valid \\
\hline & $\begin{array}{l}\text { Mengetikka } \\
\mathrm{n} \text { nama } \\
\text { pelanggan,e } \\
\text { mail dan } \\
\text { no.telepon, } \\
\text { username,p } \\
\text { assword, } \\
\text { konfirmasi } \\
\text { password,ti } \\
\text { dak diisi } \\
\text { kemudain } \\
\text { klik tombol } \\
\text { daftar }\end{array}$ & $\begin{array}{l}\text { Nama } \\
\text { pelanggan:( } \\
\text { Reza) } \\
\text { Email:(reza } \\
1215 \\
\text { @ bsi.ac.id) } \\
\text { No. } \\
\text { Telepon:(k } \\
\text { osong) } \\
\text { Username: } \\
\text { (kosong) } \\
\text { Password: } \\
\text { (kosong) } \\
\text { Konfirmasi } \\
\text { Password: } \\
\text { (kosong) }\end{array}$ & $\begin{array}{l}\text { Sistem } \\
\text { akan } \\
\text { menolak } \\
\text { akses user } \\
\text { dan } \\
\text { menampilk } \\
\text { an "Data } \\
\text { no. } \\
\text { Telepon,us } \\
\text { ername } \\
\text {,password,k } \\
\text { onfirmasi } \\
\text { Password } \\
\text { masih } \\
\text { kosong } \\
\text { ” }\end{array}$ & $\begin{array}{l}\text { Sesuai } \\
\text { harapa } \\
\mathrm{n}\end{array}$ & Valid \\
\hline & $\begin{array}{l}\text { Mengetikka } \\
\text { n nama } \\
\text { pelanggan,e } \\
\text { mail, } \\
\text { no.telepon } \\
\text { dan } \\
\text { Username, } \\
\text { password, } \\
\text { konfirmasi } \\
\text { password, } \\
\text { tidak diisi } \\
\text { kemudain } \\
\text { klik tombol } \\
\text { daftar }\end{array}$ & $\begin{array}{l}\text { Nama } \\
\text { pelanggan:( } \\
\text { Reza) } \\
\text { Email:(reza } \\
1215 \\
\text { @ bsi.ac.id) } \\
\text { No. } \\
\text { Telepon:(0 } \\
\text { 899313686 } \\
\text { 8) } \\
\text { Username: } \\
\text { (kosong) } \\
\text { Password: } \\
\text { (kosong) } \\
\text { Konfirmasi } \\
\text { Password: } \\
\text { (kosong) }\end{array}$ & $\begin{array}{l}\text { Sistem } \\
\text { akan } \\
\text { menolak } \\
\text { akses user } \\
\text { dan } \\
\text { menampilk } \\
\text { an "Data } \\
\text { username,p } \\
\text { assword,ko } \\
\text { nfirmasi } \\
\text { Password } \\
\text { masih } \\
\text { kosong } \\
\text { ". }\end{array}$ & $\begin{array}{l}\text { Sesuai } \\
\text { harapa } \\
\mathrm{n}\end{array}$ & Valid \\
\hline & Mengetikka & Nama & Sistem & Sesuai & Valid \\
\hline
\end{tabular}

\begin{tabular}{|c|c|c|c|c|}
\hline $\begin{array}{l}\text { n nama } \\
\text { pelanggan,e } \\
\text { mail, } \\
\text { no.telepon, } \\
\text { Username } \\
\text { dan } \\
\text { password, } \\
\text { konfirmasi } \\
\text { password, } \\
\text { tidak diisi } \\
\text { kemudain } \\
\text { klik tombol } \\
\text { daftar }\end{array}$ & $\begin{array}{l}\text { pelanggan:( } \\
\text { Reza) } \\
\text { Email:(reza } \\
1215 \\
\text { @bsi.ac.id) } \\
\text { No. } \\
\text { Telepon:(0 } \\
899313686 \\
\text { 8) } \\
\text { Username: } \\
\text { (reza10) } \\
\text { Password: } \\
\text { (kosong) } \\
\text { Konfirmasi } \\
\text { Password: } \\
\text { (kosong) }\end{array}$ & $\begin{array}{l}\text { akan } \\
\text { menolak } \\
\text { akses user } \\
\text { dan } \\
\text { menampilk } \\
\text { an "Data } \\
\text { password,k } \\
\text { onfirmasi } \\
\text { Password } \\
\text { masih } \\
\text { kosong } \\
\text { ". }\end{array}$ & $\begin{array}{l}\text { harapa } \\
\mathrm{n}\end{array}$ & \\
\hline $\begin{array}{l}\text { Mengetikka } \\
\text { n nama } \\
\text { pelanggan,e } \\
\text { mail, } \\
\text { no.telepon, } \\
\text { Username, } \\
\text { password } \\
\text { dan } \\
\text { konfirmasi } \\
\text { password, } \\
\text { tidak diisi } \\
\text { kemudain } \\
\text { klik tombol } \\
\text { daftar }\end{array}$ & $\begin{array}{l}\text { Nama } \\
\text { pelanggan:( } \\
\text { Reza) } \\
\text { Email:(reza } \\
1215 \\
\text { @ bsi.ac.id) } \\
\text { No. } \\
\text { Telepon:(0 } \\
\text { 899313686 } \\
\text { 8) } \\
\text { Username: } \\
\text { (reza10) } \\
\text { Password: } \\
\text { (apaaja) } \\
\text { Konfirmasi } \\
\text { Password: } \\
\text { (kosong) }\end{array}$ & $\begin{array}{l}\text { Sistem } \\
\text { akan } \\
\text { menolak } \\
\text { akses user } \\
\text { dan } \\
\text { menampilk } \\
\text { an "Data } \\
\text { konfirmasi } \\
\text { Password } \\
\text { masih } \\
\text { kosong } \\
\text { ". }\end{array}$ & $\begin{array}{l}\text { Sesuai } \\
\text { Harapa } \\
n\end{array}$ & Valid \\
\hline $\begin{array}{l}\text { Mengetikka } \\
\mathrm{n} \text { nama } \\
\text { pelanggan,e } \\
\text { mail, } \\
\text { no.telepon, } \\
\text { Username, } \\
\text { password, } \\
\text { konfirmasi } \\
\text { password, } \\
\text { kemudian } \\
\text { klik tombol } \\
\text { daftar }\end{array}$ & $\begin{array}{l}\text { Nama } \\
\text { pelanggan:( } \\
\text { Reza) } \\
\text { Email:(reza } \\
1215 \\
\text { @ bsi.ac.id) } \\
\text { No. } \\
\text { Telepon:(0 } \\
\text { 899313686 } \\
\text { 8) } \\
\text { Username: } \\
\text { (reza10) } \\
\text { Password: } \\
\text { (apaaja) } \\
\text { Konfirmasi } \\
\text { Password: } \\
\text { (apaaja) }\end{array}$ & $\begin{array}{l}\text { Sistem } \\
\text { akan } \\
\text { menerima } \\
\text { akses daftar }\end{array}$ & $\begin{array}{l}\text { Sesuai } \\
\text { Harapa } \\
n\end{array}$ & Valid \\
\hline
\end{tabular}

c. Pengujian terhadap form konfirmasi pembayaran

Tabel 3. Hasil Pengujian Blackbox Testing Form Pembayaran Customer

\begin{tabular}{|c|c|c|c|c|c|}
\hline No & $\begin{array}{l}\text { Skenario } \\
\text { pengujian }\end{array}$ & Test case & $\begin{array}{l}\text { Hasil yang } \\
\text { diharapkan }\end{array}$ & $\begin{array}{l}\text { Hasil } \\
\text { penguji } \\
\text { an }\end{array}$ & $\begin{array}{l}\text { Kesi } \\
\text { mpul } \\
\text { an }\end{array}$ \\
\hline 1 & $\begin{array}{l}\text { No } \\
\text { pemesanan, } \\
\text { nama } \\
\text { pelanggan, } \\
\text { jumlah } \\
\text { transfer, } \\
\text { keterangan } \\
\text { dalam } \\
\text { keadaan } \\
\text { kosong lalu } \\
\text { tekan } \\
\text { tombol } \\
\text { kirim }\end{array}$ & $\begin{array}{l}\text { No } \\
\text { pemesanan: } \\
\text { (kosong) } \\
\text { Nama } \\
\text { Pelanggan: } \\
\text { (kosong) } \\
\text { Jumlah } \\
\text { transfer: } \\
\text { (kosong) } \\
\text { Keterangan } \\
\text { : } \\
\text { (kosong) }\end{array}$ & $\begin{array}{l}\text { Sistem } \\
\text { akan } \\
\text { menolak } \\
\text { akses user } \\
\text { dan } \\
\text { menampilk } \\
\text { an "Data no } \\
\text { pemesanan } \\
\text { masih } \\
\text { kosong(isi } \\
\text { sesuai } \\
\text { dengan no } \\
\text { pemesanan } \\
\text { anda), } \\
\text { nama } \\
\text { pelanggan }\end{array}$ & $\begin{array}{l}\text { Sesuai } \\
\text { harapa } \\
n\end{array}$ & Valid \\
\hline
\end{tabular}




\begin{tabular}{|c|c|c|c|c|c|}
\hline & & & $\begin{array}{l}\text { masih } \\
\text { kosong(isi } \\
\text { sesuai } \\
\text { nama akun } \\
\text { anda), } \\
\text { jumlah } \\
\text { transfer } \\
\text { masih } \\
\text { kosong, dan } \\
\text { harus } \\
\text { ditulis } \\
\text { angka, data } \\
\text { keterangan } \\
\text { masih } \\
\text { kosong" }\end{array}$ & & \\
\hline 2. & $\begin{array}{l}\text { No } \\
\text { pemesanan } \\
\text { diisi dengan } \\
\text { benar, nama } \\
\text { pelanggan, } \\
\text { jumlah } \\
\text { transfer, } \\
\text { keterangan } \\
\text { dalam } \\
\text { keadaan } \\
\text { kosong lalu } \\
\text { tekan tombol } \\
\text { kirim }\end{array}$ & $\begin{array}{l}\text { No } \\
\text { pemesanan: } \\
\text { (PS0001) } \\
\text { Nama } \\
\text { Pelanggan: } \\
\text { (kosong) } \\
\text { Jumlah } \\
\text { transfer: } \\
\text { (kosong) } \\
\text { Keterangan: } \\
\text { (kosong) }\end{array}$ & $\begin{array}{l}\text { Sistem akan } \\
\text { menolak } \\
\text { akses user } \\
\text { dan } \\
\text { menampilkan } \\
\text { "Data nama } \\
\text { pelanggan } \\
\text { masih } \\
\text { kosong(isi } \\
\text { sesuai nama } \\
\text { akun anda), } \\
\text { jumlah } \\
\text { transfer } \\
\text { masih } \\
\text { kosong, dan } \\
\text { harus ditulis } \\
\text { angka, data } \\
\text { keterangan } \\
\text { masih } \\
\text { kosong" }\end{array}$ & $\begin{array}{l}\text { Sesuai } \\
\text { harapan }\end{array}$ & Valid \\
\hline 3 & $\begin{array}{l}\text { No } \\
\text { pemesanan, } \\
\text { nama } \\
\text { pelanggan } \\
\text { diisi } \\
\text { dengan } \\
\text { benar, } \\
\text { jumlah } \\
\text { transfer, } \\
\text { keterangan } \\
\text { dalam } \\
\text { keadaan } \\
\text { kosong lalu } \\
\text { tekan } \\
\text { tombol } \\
\text { kirim }\end{array}$ & $\begin{array}{l}\text { No } \\
\text { pemesanan: } \\
\text { (PSO001) } \\
\text { Nama } \\
\text { Pelanggan: } \\
\text { (Reza) } \\
\text { Jumlah } \\
\text { transfer: } \\
\text { (kosong) } \\
\text { Keterangan } \\
\text { : } \\
\text { (kosong) }\end{array}$ & $\begin{array}{l}\text { Sistem } \\
\text { akan } \\
\text { menolak } \\
\text { akses user } \\
\text { dan } \\
\text { menampilk } \\
\text { an "Data } \\
\text { jumlah } \\
\text { transfer } \\
\text { masih } \\
\text { kosong, dan } \\
\text { harus } \\
\text { ditulis } \\
\text { angka, data } \\
\text { keterangan } \\
\text { masih } \\
\text { kosong" }\end{array}$ & $\begin{array}{l}\text { Sesuai } \\
\text { harapa } \\
n\end{array}$ & $\begin{array}{l}\text { Vali } \\
\text { d }\end{array}$ \\
\hline 4 & $\begin{array}{l}\text { No } \\
\text { pemesanan, } \\
\text { nama } \\
\text { pelanggan, } \\
\text { jumlah } \\
\text { transfer diisi } \\
\text { dengan } \\
\text { benar, } \\
\text { keterangan } \\
\text { dalam } \\
\text { keadaan } \\
\text { kosong lalu } \\
\text { tekan } \\
\text { tombol } \\
\text { kirim } \\
\end{array}$ & $\begin{array}{l}\text { No } \\
\text { pemesanan: } \\
\text { (PS0001) } \\
\text { Nama } \\
\text { Pelanggan: } \\
\text { (Reza) } \\
\text { Jumlah } \\
\text { transfer: } \\
\text { (100.000) } \\
\text { Keterangan: } \\
\text { (kosong) }\end{array}$ & $\begin{array}{l}\text { Sistem akan } \\
\text { menolak } \\
\text { akses user } \\
\text { dan } \\
\text { menampilka } \\
\text { n "Data } \\
\text { keterangan } \\
\text { masih } \\
\text { kosong" }\end{array}$ & $\begin{array}{l}\text { Sesuai } \\
\text { harapan }\end{array}$ & Valid \\
\hline 5 & $\begin{array}{l}\text { No } \\
\text { pemesanan, } \\
\text { nama } \\
\text { pelanggan, } \\
\text { jumlah } \\
\text { transfer, } \\
\text { keterangan } \\
\text { diisi dengan }\end{array}$ & $\begin{array}{l}\text { No } \\
\text { pemesanan: } \\
\text { (PS0001) } \\
\text { Nama } \\
\text { Pelanggan: } \\
\text { (Reza) } \\
\text { Jumlah } \\
\text { transfer: }\end{array}$ & $\begin{array}{l}\text { Sistem akan } \\
\text { menerima } \\
\text { akses user } \\
\text { dan } \\
\text { menampilka } \\
\text { n "sukses! } \\
\text { Konfirmasi } \\
\text { Sudah }\end{array}$ & $\begin{array}{l}\text { Sesuai } \\
\text { harapan }\end{array}$ & Valid \\
\hline
\end{tabular}

\begin{tabular}{lll}
\hline benar & lalu & $(100.000)$ \\
tekan & Keterangan: & \\
tombol & (sudh & \\
kirim & transfer) & \\
\hline
\end{tabular}

\section{KESIMPULAN}

Berdasarkan pembahasan yang dijelaskan penulis pada bab-bab sebelumnya, penulis mengambil kesimpulan, diantaranya:

1. Dengan menggunakan internet penyebaran informasi semakin cepat dan efektif

2. Dengan menggunakan website kita dapat dengan mudah memperluas wilayah pemasaran produk sehingga dapat meningkatkan penjualan yang kita promosikan.

3. Dengan adanya web e-comerce yaitu memberikan kemudahan bagi masyarakat dalam berbelanja, dengan mengakses internet masyarakat dapat melihat, memilih dan memesan produk yang diinginkan kapanpun dan dimanapun mereka berada.

4. Dengan menggunakan media online dapat memudahkan transaksi jual beli tanpa harus datang ke toko langsung.

\section{PUSTAKA}

Andi. (2013). Mahir Dalam 7 Hari Adobe Dreamweaver CS6 Dengan Pemrograman PHP $\&$ MySQL.

Anhar. (2016). Panduan Bijak Belajar Internet Untuk Anak.

Dadan, \& Developers, K. (2015). Membuat CMS Multifitur.

Febriyansyah, R., Bijaksana, A., Negara, P., Safriadi, N., Studi, P., Informatika, T., ... Pendahuluan, I. (2017). Rancang bangun aplikasi pemesanan menu di restoran berbasis web, 5(3), 3-7.

Hasan, N. (2014). PERANCANGAN APLIKASI ECOMMERCE PENJUALAN KOMPUTER, (1), 81-88.

Hastanti, R. P., Eka, B., Indah, P., \& Wardati, U. (2015). Sistem Penjualan Berbasis Web ( ECommerce ) Pada Tata Distro Kabupaten Pacitan, 3(2), 1-9.

Hidayatullah, P., \& Kawistara, J. K. (2015). PEMROGRAMAN WEB.

Journal, I. (2014). IJNS - Indonesian Journal on Networking and Security - Volume 3 No 1 Januari 2014 - http://ijns.org, 3(1), 32-38.

Kosasi, S. (2015). Perancangan Sistem E-Commerce Untuk Memperluas Pasar Produk Oleh-Oleh Khas Pontianak, 110-119.

Ningrum, D. P. (2013). Sistem Informasi Penjualan Dream Catcher Berbasis Web, (18).

Nugroho, B. (2013). Dasar Pemrograman Web PHPmySQL Dengan Dreamweaver.

Rusdi, I., \& Mashabi, M. A. (2017). Sistem Informasi Kependudukan di Rukun Tetangga 04 
/ 08 Kelurahan Utan Panjang Berbasis Web, 12550(1), 9-15.

Sidik, B. (2013). Javascript.

Sidik, B. (2014). Pemrograman Web dengan PHP.

Sidik, B., \& Pohan, H. I. (2015). Pemrograman WEB demgan HTML (p. 1).

Soekamto, R. A., \& Shalahuddin, M. (2018). Rekayasa Perangkat Lunak (p. 29).

Solichin, A. (2016). Pemrograman Web Dengan Php Dan Mysql.

Widodo, A. W., \& Kurnianingtyas, D. (2017). Sistem Basis Data. 